
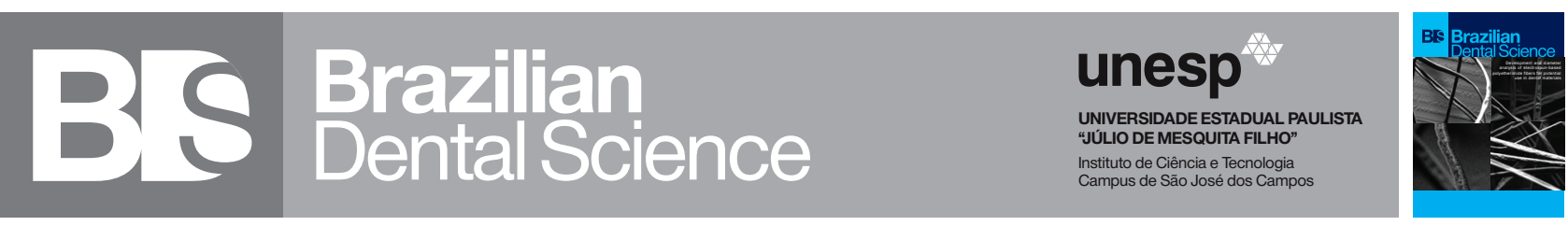

\title{
Photosensitizers And Exposure Times To Light Showed Tissue Compatibility In Isogenic Mice
}

Fotossensibilizadores e Tempo de Exposição a Luz em Relação a Compatibilidade de Tecidos em Ratos Isogênicos

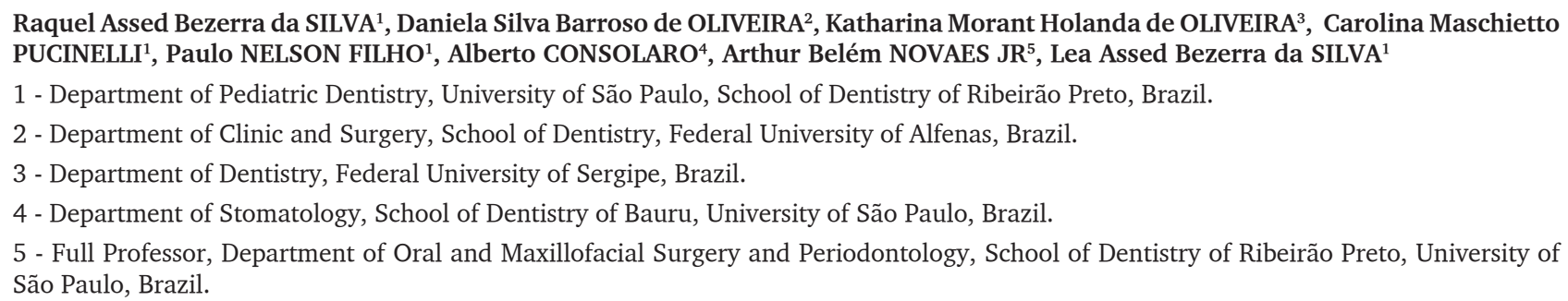
São Paulo, Brazil.

\begin{abstract}
Objective: The aim of this study was to evaluate the subcutaneous tissue response after different protocols to photodynamic therapy (PDT). In Phase 1, were tested the diode laser (used for $1 \mathrm{~min}$ ) associated to the photosensitizer phenothiazine chloride solution (PCS) in different concentrations. In Phase 2 - the diode laser and LED were tested associated to two different photosensitizers, PCS and Curcumin, in differentexposure times of light application. Material and Methods: After 7, 21 and 63-days the animals were euthanized and the subcutaneous tissue processed to histological analysis. Qualitative and semi-quantitative descriptions of the inflammatory process and immunohistochemical technique were performed. The obtained data were analyzed by Kruskal-Wallis and Dunn's post-test ( $\alpha$ $=0.5$ ). Results: On Phase 1, the tissue response was very similar among the groups. For the inflammatory infiltrate, PCS with concentration of $10 \mathrm{mg} / \mathrm{mL}$ exhibited the most intense reaction $(p>0.05)$. On Phase 2 , at 7-days period, the analyzed parameters presented small magnitude and after 21 and 63-days, all the parameters demonstrated tissue compatibility. Conclusion: Both photosensitizers presented proper tissue compatibility regardless the different concentrations used on Phase 1 and different durations of light exposure on Phase 2.
\end{abstract}

\section{KEYWORDS}

Photodynamic therapy; Phenothiazine chloride solution; Curcumin; Isogenic mice; Subcutaneous tissue.

\section{RESUIMO}

Objetivo: Este estudo avaliou a resposta do tecido subcutâneo após terapia fotodinâmica, utilizando na Fase 1 - laser diodo por 1min e solução fotossensibilizadora de cloreto de fenotiazina (CF) em diferentes concentrações e Fase 2 - laser diodo e LED e dois fotossensibilizadores, CF e Curcumina, em diferentes tempos de exposição da aplicação de luz. Material e Métodos: Após 7, 21 e 63 dias, foram realizadas descrições qualitativas e semiquantitativas do processo inflamatório e técnica de imunoistoquímica. Os dados foram analisados pelo pós-teste de Kruskal-Wallis e Dunn $(\alpha=0,5)$. Resultados: $\mathrm{Na}$ Fase 1, a resposta do tecido foi muito semelhante. $\mathrm{O}$ infiltrado inflamatório, na concentração de $10 \mathrm{mg} / \mathrm{mL}$, exibiu reação mais intensa $(\mathrm{p}>0,05)$. Na Fase 2, aos 7 dias, os parâmetros analisados apresentaram pequena magnitude. Aos 21 e 63 dias, todos os parâmetros demonstraram compatibilidade com o tecido. Conclusão: Ambos os fotossensibilizadores apresentaram compatibilidade de tecido adequada, independentemente das diferentes concentrações utilizadas na Fase 1 e diferentes durações de exposição à luz na Fase 2.

\section{PALAVRAS-CHAVE}

Terapia fotodinâmica; Solução de cloreto de fenotiazina; Curcumina; Ratos isogênicos; Tecido subcutâneo. 


\section{INTRODUCTION}

$\mathrm{T}_{\mathrm{H}}^{\mathrm{h}}$ he photodynamic therapy (PDT) is a treatment in which one photoactive agent, known as photosensitizer, is activated by a light with a specific wavelength, triggering the production of singlet oxygen, superoxide and free radicals (reactive oxygen species), that are cytotoxic to target cells [1-4] leading to cellular death by oxidation of biological molecules such as proteins, nucleic acids and lipids [5].

The antimicrobial efficiency of PDT in Dentistry has been evaluated in several studies $[1,3,4]$. However, there are few studies presenting the microscopic biologic effects of this treatment in Dentistry, in different tissues (oral mucosa, periodontal tissues, oral mucosal ulcer and periapical tissues) after performing different protocols [2,6-15].

According to Luan et al. (2016) [6], in periodontal tissues no significant histologic differences (inflammatory infiltrate, necrosis or vascular alterations) was noted in the tissues treated with PDT. On the other hand, Garcia et al., 2014 [8] observed a small and isolated number of inflammatory cells located in dense conjunctive tissue, composed by a large amount of collagen fibers and few fibroblasts, in teeth with induced periodontitis treated by scaling and root planning followed by PDT.

Three previous studies performed by our research group in dog's teeth with experimental induced periapical lesions, evaluated the response of the apical and periapical tissues after PDT $[2,10,12]$. Although the PDT presented important results indicative of repair process, such as moderate collagen fiber formation and angiogenesis [2], the calcium hydroxide intracanal dressing overcome these results. Together, the results of those three papers showed the importance of the evaluation of different parameters for better results after the use of PDT, without damages for tissue repair process.

Furthermore, considering the influence of the different parameters to perform PDT, including type of laser, light wavelength $(\mathrm{nm})$, energy density $\left(\mathrm{J} / \mathrm{cm}^{2}\right)$, intensity or potency (W), and the great variety of chemical composts that can be used as photosensitizers, in variable concentrations [1-4,6-12], biological investigations of PDT are mandatory.

Therefore, this study aimed to evaluate the tissue response in mice's dorsal subcutaneous, after performing PDT, in different conditions: Phase 1 - photosensitizer phenothiazine chloride solution in different concentrations and Phase 2 - two photosensitizers (Phenothiazine chloride solution and Curcumin), with the different laser exposure times.

\section{MATERIAL AND METHODS}

\section{Animals}

All the procedures were submitted and approved by the Ethic Committee in the Use of Animals (CEUA), from the School of Dentistry of Ribeirão Preto, University of São Paulo (FORP/ USP) (process number 2015.1.598.58.1).

\section{Surgical procedures}

The experimental procedures were based on the standards proposed by the International Organization for Standardization (ISO) no 7405, 2008. Two hundred and twenty-five (225) isogenic BALB/c mice, males, aged 6 to 8 weeks, weighting 15 to 20 grams were.

Animals were anesthetized with an intramuscular injection of $10 \%$ Ketamine (Agener União Química Farmacêutica Nacional S/A, Embu-Guaçu, Brazil) and 2\% Xylazine (Dopaser, Laboratórios Calier, Barcelona, Spain), $35 \mathrm{mg} / \mathrm{kg}$ and $7 \mathrm{mg} / \mathrm{kg}$, respectively. Next, dorsal region was shaved and cleaned with a $1 \%$ chlorhexidine gluconate solution (Assepmed -Medquímica - Juiz de Fora - MG).

Before the surgical procedure, a 2 $\mathrm{cm}^{2}$ area on the animal dorsal region was demarcated, in order to standardized where the photosensitizer and the light were applied. An incision of $2 \mathrm{~cm}$ length was made on the dorsal 
region followed by tissue divulsion, insertion of the photosensitizer into the connective tissue followed by the application of the light with the wavelength compatible to the photosensitizer.

The present study was divided in two experimental phases, as described:

Phase 1: 99 mice were used to evaluate different dilutions of the Phenothiazine chloride solution (Helbo Blue Photossensitizer - Helbo Photodynamic Systems GmbH \& Co KG, Grieskirchen, Austria): 10mg/mL (original concentration), $1,0 \mathrm{mg} / \mathrm{mL}, 0,1 \mathrm{mg} / \mathrm{mL}$, and $0,005 \mathrm{mg} / \mathrm{mL}$ [2]. The photosensitizer was applied on the previously demarcated area and maintained for $1 \mathrm{~min}$ (pre-irradiation period), following the manufacturer's instructions. After this period, the tissue was washed with $5 \mathrm{~mL}$ of distilled water, and the solution excess was removed using sterile gauze. Next, a diode laser was applied (Helbo Therapielaser, Helbo Photodynamic Systems GmbH \& Co KG, Grieskirchen, Austria - 660nm wavelength and energy density of $3.3 \mathrm{~J} / \mathrm{cm}^{2}$ ) for one min, also as recommended by the manufacturer.

Table I - Distribution of groups, experimental periods and number of animals used on Phase1

\begin{tabular}{ccc}
$\begin{array}{c}\text { Experimental } \\
\text { Periods }\end{array}$ & \multicolumn{1}{c}{ Groups } & $\begin{array}{c}\text { Number of } \\
\text { animals }\end{array}$ \\
& Phenothiazine chloride solution $10 \mathrm{mg} / \mathrm{mL}$ & 07 \\
& Phenothiazine chloride solution $1,0 \mathrm{mg} / \mathrm{mL}$ & 07 \\
7 days & Phenothiazine chloride solution $0,1 \mathrm{mg} / \mathrm{mL}$ & 07 \\
& Phenothiazine chloride solution $0,005 \mathrm{mg} / \mathrm{mL}$ & 07 \\
& Control & 05 \\
& Phenothiazine chloride solution $10 \mathrm{mg} / \mathrm{mL}$ & 07 \\
& Phenothiazine chloride solution $1,0 \mathrm{mg} / \mathrm{mL}$ & 07 \\
21 days & Phenothiazine chloride solution $0,1 \mathrm{mg} / \mathrm{mL}$ & 07 \\
& Phenothiazine chloride solution $0,005 \mathrm{mg} / \mathrm{mL}$ & 07 \\
& Control & 05 \\
& Phenothiazine chloride solution $10 \mathrm{mg} / \mathrm{mL}$ & 07 \\
& Phenothiazine chloride solution $1,0 \mathrm{mg} / \mathrm{mL}$ & 07 \\
63 days & Phenothiazine chloride solution $0,1 \mathrm{mg} / \mathrm{mL}$ & 07 \\
& Phenothiazine chloride solution $0,005 \mathrm{mg} / \mathrm{mL}$ & 07 \\
& Control & 05
\end{tabular}

\section{Phase 2}

126 mice were used to compare two photosensitizers, phenothiazine chloride solution (Helbo Blue Photosensitizer - Helbo Photodynamic Systems GmbH \& Co KG, Grieskirchen, Austria) at $10 \mathrm{mg} / \mathrm{mL}$ (based on Phase 1), and Curcumin in the concentration of $0.0074 \mathrm{mg} / \mathrm{mL}$ [4]. Curcumin (Sigma Aldrich, St. Louis, MO, USA, molecular weight 368.68) was initially diluted in 10\% DMSO, giving rise to a concentrated stock solution, which was adjusted in distilled water to the concentration of $0.0074 \mathrm{mg} / \mathrm{mL}$ [4]. The initial dilution in DMSO was necessary to ensure the solubilization of the insoluble powder in aqueous vehicles and its stability, since it is sensitive to variations in ambient temperature and can generate free radicals [19]. The phenothiazine chloride solution was applied for a period of $1 \mathrm{~min}$ (preirradiation period), following the manufacturer's instructions. The Curcumin was applied on the demarcated area with a pre-irradiation period of $5 \mathrm{~min}$ [4]. After this period, the tissue was washed as described on Phase 1. Also, three different exposure times of the photosensitizers to the laser (Helbo Therapielaser, Helbo Photodynamic Systems GmbH \& Co KG, Grieskirchen, Austria - 660nm wavelength and energy density of $3.3 \mathrm{~J} / \mathrm{cm}^{2}$ ) were used to the irradiation of the phenothiazine chloride solution, and LED (RadiiCal, SDI Limited, Bayswater, Victoria, Austrália - 450nm wavelength and energy density of 72 $\mathrm{J} / \mathrm{cm}^{2}$ ) used for the Curcumin evaluation (30 seconds, $1 \mathrm{~min}$ and $2 \mathrm{~min}$ ).

In the control groups, only the incision and divulsion of the tissue was performed, in order to evaluate the inflammatory response caused by the surgical procedure (sham animals). The animals used as control were the same to both experimental phases.

After conclusion of the experimental procedures, the skin borders were closed with 4-0 silk sutures (Vicryl; Johnson \& Johnson: Ethicon Inc., New Brunswick, USA). The animals were kept with free access to standard diet and water during the experimental periods and were 
periodically observed for local, systemic and behavioral abnormalities.

After each experimental period (7, $21 \mathrm{e}$ 63 days), the animals were killed by a mixture of ketamine and xylazine and a sample of the subcutaneous connective tissue and skin, involving the treated area, with the standard dimension of $6 \mathrm{~mm}^{2}$ from the center of the surgical wound, was removed, fixated in 10\% buffered formalin for 24 hours, and then subjected to the histological processing.

Table II describe the experimental and control groups, number of animals in each group and experimental periods for Phase 2 .

Table II - Distribution of groups, experimental periods and number of animals on Phase 2

\begin{tabular}{|c|c|c|}
\hline $\begin{array}{l}\text { Experimental } \\
\text { Periods }\end{array}$ & Groups & $\begin{array}{c}\text { Number of } \\
\text { animals }\end{array}$ \\
\hline \multirow{7}{*}{7 days } & Phenothiazine chloride solution $30 \mathrm{~s}$ & 07 \\
\hline & Phenothiazine chloride solution $1 \mathrm{~min}$ & 07 \\
\hline & Phenothiazine chloride solution $2 \mathrm{~min}$ & 07 \\
\hline & Curcumin $30 \mathrm{~s}$ & 07 \\
\hline & Curcumin $1 \mathrm{~min}$ & 07 \\
\hline & Curcumin 2 min & 07 \\
\hline & Control & 05 \\
\hline \multirow{7}{*}{ 21 days } & Phenothiazine chloride solution $30 \mathrm{~s}$ & 07 \\
\hline & Phenothiazine chloride solution 1 min & 07 \\
\hline & Phenothiazine chloride solution $2 \mathrm{~min}$ & 07 \\
\hline & Curcumin $30 \mathrm{~s}$ & 07 \\
\hline & Curcumin $1 \mathrm{~min}$ & 07 \\
\hline & Curcumin $2 \mathrm{~min}$ & 07 \\
\hline & Control & 05 \\
\hline \multirow{7}{*}{63 days } & Phenothiazine chloride solution $30 \mathrm{~s}$ & 07 \\
\hline & Phenothiazine chloride solution $1 \mathrm{~min}$ & 07 \\
\hline & Phenothiazine chloride solution $2 \mathrm{~min}$ & 07 \\
\hline & Curcumin $30 \mathrm{~s}$ & 07 \\
\hline & Curcumin $1 \mathrm{~min}$ & 07 \\
\hline & Curcumin 2 min & 07 \\
\hline & Control & 05 \\
\hline
\end{tabular}

\section{Histological Processing}

After fixation, the tissue was embedded in paraffin and $5 \mu \mathrm{m}$-thick semi serial sections were obtained, stained with hematoxylin and eosin, Picrosirius or prepared to immunohistochemical staining. Then, the slides were examined under light microscopy using the microscope Axio Imager.M1 (Carl Zeiss MicroImaging GmbH, Göttingen, Germany), coupled to an AxioCam MRc5 camera (Carl Zeiss MicroImaging GmbH, Göttingen, Germany), by an experienced pathologist blinded to the analyzed groups.

\section{Descriptive and Semi-Quantitative Microscopic Analysis}

Sections stained with H\&E were used to perform the description of the tissue reaction in relation to the photosensitizers and laser exposures, in the different experimental periods, on both Phases 1 and 2 .

Also, using the same H\&E sections used to the descriptive analysis, scores from 0 to 3 were attributed, to the following parameters [20]:

- collagen fiber formation - 0: absent; 1 : mild; 2 : moderate; 3 : severe.

- tissue thickness - 0: normal; 1 : slightly expanded; 2 : moderately expanded; 3 : severely expanded.

- inflammatory infiltrate - 0: absent; 1: mild inflammatory infiltrate; 2 : moderate inflammatory infiltrate; 3 : intense inflammatory infiltrate.

\section{Immunohistochemistry for neutrophils and macrophages}

In order to identify the presence of neutrophils and macrophages in the reactive tissue, immunohistochemistry was performed, on both Phases 1 and 2. Slides were deparaffinized and hydrated, antigenic recovery performed by heat and immersion in citrate buffer $(\mathrm{pH}=6,0)$ using microwave oven (12 cycles of 10 second each). The slides were washed and the endogenous peroxidase was blocked using 3\% hydrogen peroxide, for 20min. After washing again, the block of 
unspecific ligations was performed using BSA at $1 \%$ (bovine serum albumin)/PBS for $30 \mathrm{~min}$. Next, the slides were incubated overnight in 4 $\mathrm{oC}$ with the primary antibodies diluted in BSA at 1\% (anti-macrophage SC101447, dilution 1:50 and anti-neutrophil SC59338, dilution 1:100 Santa Cruz Biotechnology Inc., Dallas, USA).

After returning to room temperature, the slides were washed and incubated with biotinylated secondary antibody diluted in BSA at $1 \%$ (for macrophage goat anti-rabbit IgG-B SC2040, dilution 1:200 and for neutrophil rabbit anti-goat IgG-B SC2774, dilution 1:200 - Santa Cruz Biotechnology Inc., Dallas, USA), for 1 hour, at room temperature. Next, the strepavitinbiotin-peroxidase complex (ABC kit, Vectastain; Vector Laboratories Inc., Burlingame, USA) was applied for $30 \mathrm{~min}$. Then, the reaction was performed using the diaminobenzidine solution (DAB; Sigma-Aldrich Corporation, Saint Louis, USA) and $\mathrm{H} 2 \mathrm{O} 2$ at $3 \%$ in PBS for 1 min. The slides were counterstained with Harris hematoxylin for 10 seconds, washed in running water, washed in ammoniac water for 30 seconds, and then, once more, washed in running water. The slides were, then, diaphanized, dehydrated and settled. In the negative control, the primary antibody was substituted by non-immune serum.

The analysis was performed under normal light microcopy. The results were disclosed qualitative, according to be presence/absence of the immunostained cells.

\section{Statistical Analysis}

Considering the obtained data (scores), the results were expressed in median, first and second quartiles and analyzed by Kruskal-Wallis test. In the groups that significant statistical differences were found, the Dunn's post-test was applied. The results were analyzed using the Sigma Plot 12.0® program (Systat Software Inc., San Jose, USA). The significance level was $5 \%$.

\section{RESULTS}

\section{Phase 1}

\section{Descriptive and Semi-Quantitative Microscopic Analysis}

The description of the tissue reaction after the exposure to the photosensitizer (phenothiazine chloride solution) was similar regarding the parameter tissue thickness for all tested concentrations $(10,1,0.1$ and $0.005 \mathrm{mg} /$ $\mathrm{mL}$ ) and time points (7, 21 and 63 days). Regarding the fiber collagen formation, at 7 days, phenothiazine chloride solution at 0,1 and $10 \mathrm{mg} / \mathrm{mL}$ presented score 0 (absent formation) with statistical difference with other groups (p $<0.05$ ) After that, at 21 and 63 days, all groups presented score 1 (mild) with no statistical differences $(\mathrm{p}=1.0)$.

Regarding the inflammatory infiltrate, the concentration of $10 \mathrm{mg} / \mathrm{mL}$ induced a more intense reaction $(\mathrm{p}<0,001)$ that persists over time and maintained until the later one (score 1 ). Regarding the other tested concentrations $(1, \quad 0.1$ and $0.005 \mathrm{mg} / \mathrm{mL}$ ), inflammatory infiltrate magnitude diminished over time turning to absent in the later time point (score 0 ). The control group presented difference for the inflammatory infiltrate when compared to the $10 \mathrm{mg} / \mathrm{mL}$ concentration group in all three evaluated time-points $(\mathrm{p}<0,001)$.

In general, the tissue reactional showed mild fiber collagen formation, moderate infiltrated of macrophages and numerous fibroblastic and endothelial cells, forming a fine and delicate collagen capsular structure. At the end of the experimental periods, all the tested concentrations of the phenothiazine chloride solution presented tissue compatibility (Figure 1) (Table III). The control group presented a thin capsular structure, with few collagen fibers, however, well organized and permeated by macrophages and fibroblasts. The absence of neutrophils was characteristic. The organization, thickness and structural composition of the reactive tissue were very similar to the experimental groups. 

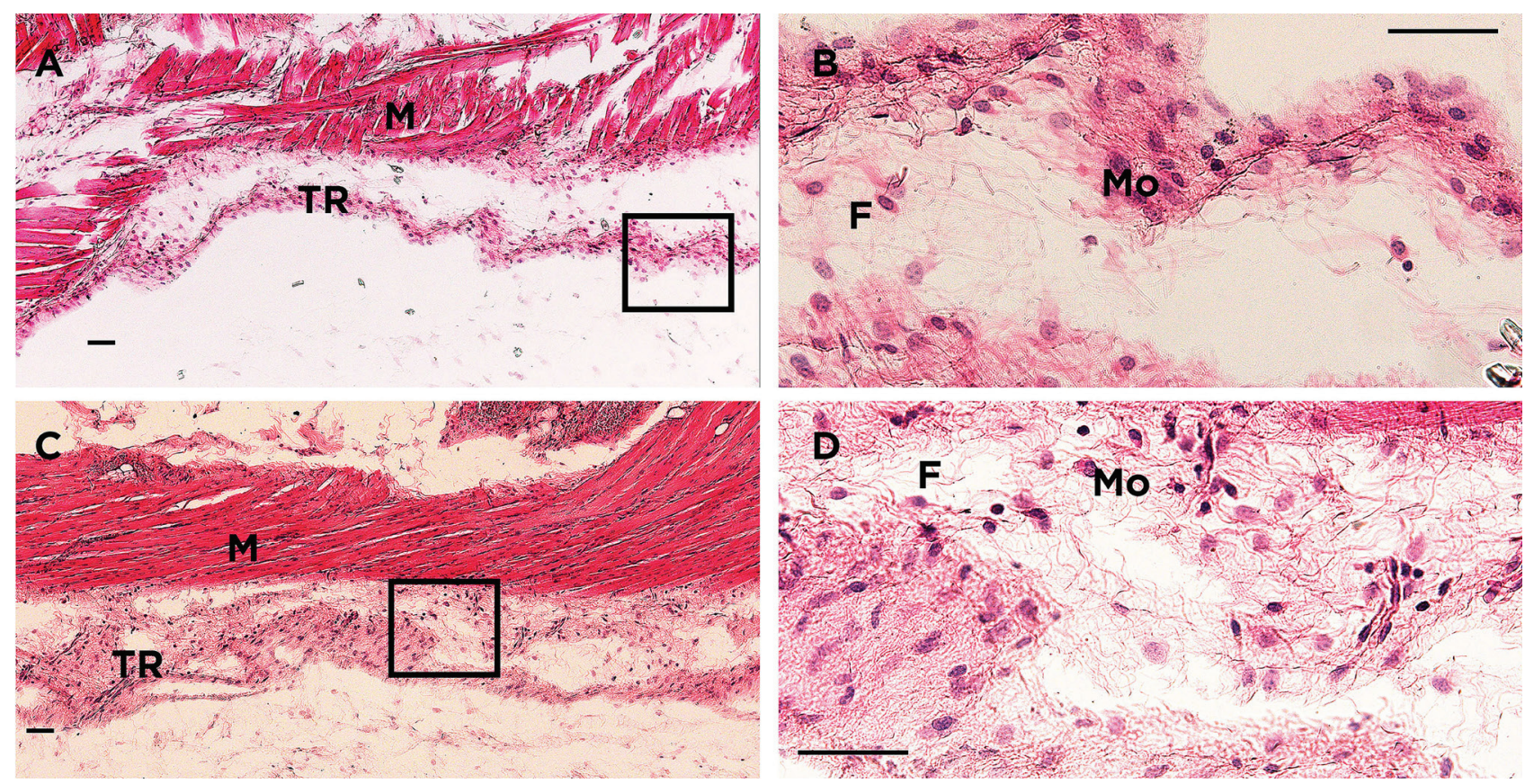

Figure 1 - Microscopic aspects representing the inflammatory reaction in the subcutaneous tissue after the use of phenothiazine chloride solution, in different concentrations (Phase 1). M: muscle, TR: reactive tissue, Mo: macrophage, F: fibroblast (Hematoxylin and Eosin - scale bar $=50 \mu \mathrm{m})$.

Table III - Statistical analyses of median values obtained on Phase 1 related to collagen fiber formation, tissue thickness and inflammatory infiltrate, after using the photosensitizer Phenothiazine chloride solution in all concentrations in the periods of 7,21 and 63 days (1Q: $1^{\circ}$ quartile; $3 Q: 3^{\circ}$ quartile)

\begin{tabular}{|c|c|c|c|c|}
\hline $\begin{array}{l}\text { Experimental } \\
\text { Periods }\end{array}$ & Groups & $\begin{array}{c}\text { Colagen Fiber Formation } \\
(1 Q-3 Q)\end{array}$ & $\begin{array}{c}\text { Tissue Thickness } \\
(1 Q-3 Q)\end{array}$ & $\begin{array}{l}\text { Inflammatory Infiltrate. } \\
\qquad(1 Q-3 Q)\end{array}$ \\
\hline \multirow{6}{*}{7 days } & Phenothiazine chloride solution $10 \mathrm{mg} / \mathrm{mL}$ & $0^{\mathrm{ab}}(0-0)$ & $2^{\mathrm{a}}(1-2)$ & $2^{\mathrm{a}}(2-2)$ \\
\hline & Phenothiazine chloride solution $1,0 \mathrm{mg} / \mathrm{mL}$ & $\mathrm{ab}^{\mathrm{ab}}(1-1)$ & $1^{b}(1-2)$ & $1^{\mathrm{ab}}(1-2)$ \\
\hline & Phenothiazine chloride solution $0,1 \mathrm{mg} / \mathrm{mL}$ & $0^{\mathrm{a}}(0-0)$ & $1 c(1-1)$ & $1^{\mathrm{ab}}(1-1)$ \\
\hline & Phenothiazine chloride solution $0,005 \mathrm{mg} / \mathrm{mL}$ & $1^{b}(1-1)$ & $1^{c}(1-1)$ & $1^{b}(0-1)$ \\
\hline & Control & $1^{\mathrm{ab}}(1-1)$ & $1^{c}(1-1)$ & $0^{\mathrm{b}}(0-0)$ \\
\hline & p value (Kruskall-Wallis test) & $p<0,001$ & $p=0,005$ & $p<0,001$ \\
\hline \multirow{6}{*}{21 days } & Phenothiazine chloride solution $10 \mathrm{mg} / \mathrm{mL}$ & $0^{\mathrm{a}}(0-0)$ & $1 \mathrm{a}(1-1)$ & $1^{a}(1-1)$ \\
\hline & Phenothiazine chloride solution $1,0 \mathrm{mg} / \mathrm{mL}$ & $1^{a}(1-1)$ & $1^{a}(1-1)$ & $0^{b}(0-0)$ \\
\hline & Phenothiazine chloride solution $0,1 \mathrm{mg} / \mathrm{mL}$ & $0^{\mathrm{a}}(0-0)$ & $1^{a}(1-1)$ & $0^{\mathrm{b}}(0-0)$ \\
\hline & Phenothiazine chloride solution $0,005 \mathrm{mg} / \mathrm{mL}$ & $1^{a}(1-1)$ & $1 \mathrm{a}(1-1)$ & $0^{b}(0-0)$ \\
\hline & Control & $1^{a}(1-1)$ & $1^{a}(1-1)$ & $0^{\mathrm{b}}(0-0)$ \\
\hline & p value (Kruskall-Wallis test) & $p=1,0$ & $p=0,446$ & $p<0,001$ \\
\hline \multirow{6}{*}{63 days } & Phenothiazine chloride solution $10 \mathrm{mg} / \mathrm{mL}$ & $0^{\mathrm{a}}(0-0)$ & $1^{a}(1-1)$ & $1^{a}(1-1)$ \\
\hline & Phenothiazine chloride solution $1,0 \mathrm{mg} / \mathrm{mL}$ & $1^{a}(1-1)$ & $1 \mathrm{a}(1-1)$ & $0^{b}(0-0)$ \\
\hline & Phenothiazine chloride solution $0,1 \mathrm{mg} / \mathrm{mL}$ & $0^{\mathrm{a}}(0-0)$ & $1 \mathrm{a}(1-1)$ & $0^{b}(0-0)$ \\
\hline & Phenothiazine chloride solution $0,005 \mathrm{mg} / \mathrm{mL}$ & $1^{a}(1-1)$ & $1 \mathrm{a}(1-1)$ & $0^{b}(0-0)$ \\
\hline & Control & $1^{a}(1-1)$ & $1^{a}(1-1)$ & $0^{\mathrm{b}}(0-0)$ \\
\hline & p value (Kruskall-Wallis test) & $p=1,0$ & $p=1,0$ & $p<0,001$ \\
\hline
\end{tabular}

* Different superscript letters indicate statistically significant differences (Dunn's Post-test; $p<0,05$ ). 


\section{Phase 2}

\section{Descriptive and Semi-Quantitative Microscopic Analysis}

Regarding phenothiazine chloride solution, at 7 and 21 days, the reactive capsule presented thin thickness characterized by a discreet collagen formation. In some specimens, there was a greater collagen fiber formation, with a moderate degree. There was a moderate inflammatory infiltrate with sparsely distributed inflammatory cells, in a diffuse format. At 63 days, the fibrotic capsule tissue exhibited remodeling characteristics, such as new fibroblasts cells and collagen fibers. From 21 to 63 days, this inflammatory infiltrate became progressively discreet, until total absence in most of the specimens at 63 days (Figures $2 \mathrm{~A}$ and $\mathrm{B}$ ).

Similarly, regarding curcumin, at 7 and 21 days, the reactive capsule presented thin and slightly collagenized, with collagen formation varying from mild to moderate. At 63 days, in the group which received the laser exposure for $2 \mathrm{~min}$, the fibrous capsule presented very heterogenic with variable degrees of collagen fiber formation. At 7 days, after 2 min laser exposure, the inflammatory infiltrate was characterized as moderate. In the subsequent periods, the observed inflammatory infiltrate was mild, diffuse and disorganized, with some leukocytes randomly distributed, and, in some cases, absent (Figure $2 \mathrm{C}$ and D).
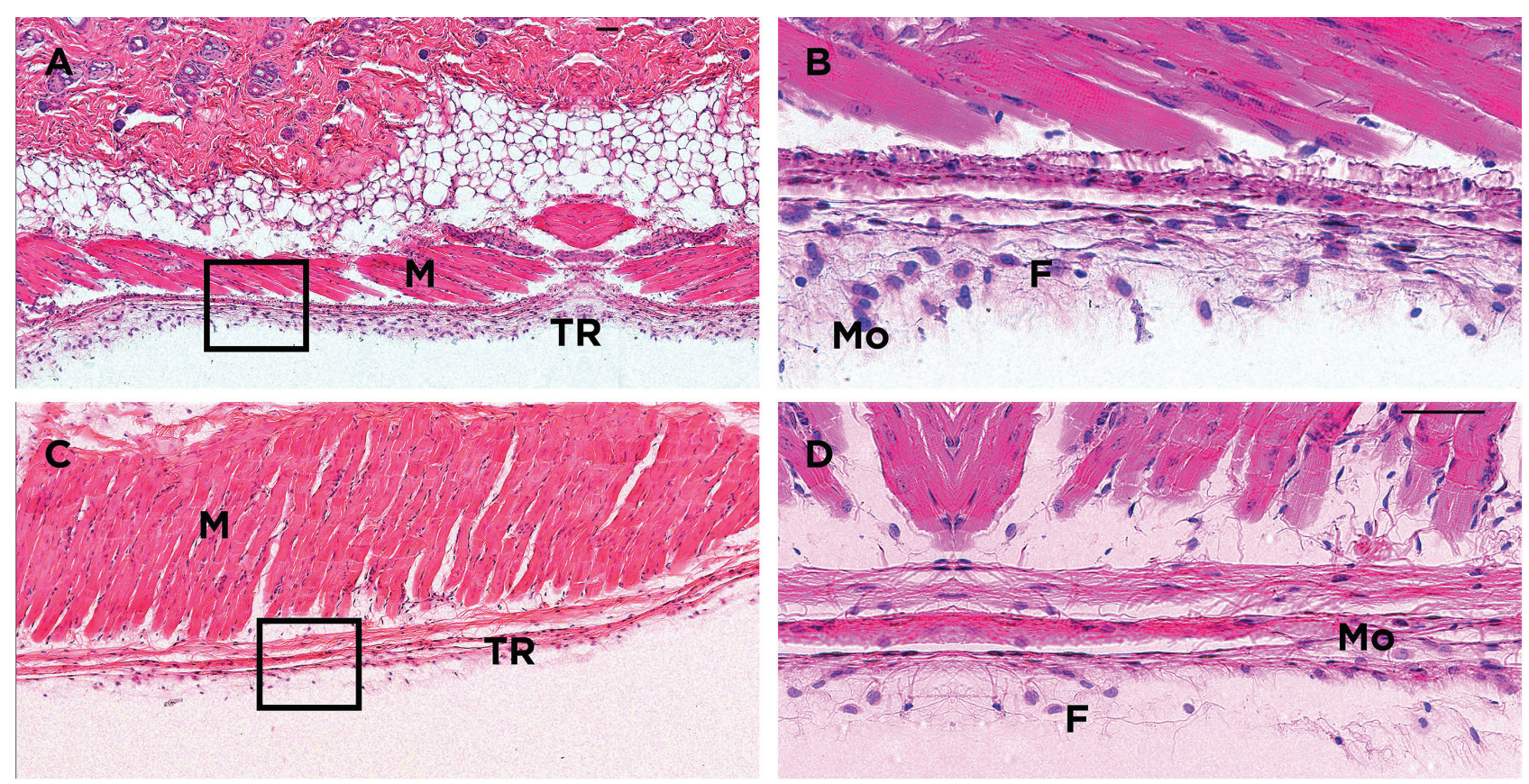

Figure 2 - Microscopic aspects representing the inflammatory reaction in the subcutaneous tissue after the use of phenothiazine chloride solution ( $\mathrm{A}$ and $\mathrm{B}$ ) and curcumin ( $\mathrm{C}$ and $\mathrm{D}$ ), in different laser application duration (Phase 2). M: muscle, TR: reactive tissue Mo: macrophage, F: fibroblast (Hematoxylin and Eosin - scale bar $=50 \mu \mathrm{m}$ ). 
Regarding the parameters collagen fiber formation, tissue thickness and inflammatory infiltrate microscopy results showed that, in the initial period of 7 days, tissue alterations were of mild magnitude. Regarding the parameter tissue thickness, the two photosensitizers were statistically different, especially when the light was applied for twomin $(\mathrm{p}<0,005)$ and the inflammatory infiltrate was more intense to the Phenothiazine chloride solution after 30 seconds and twomin of light exposure, when compared to the control $(\mathrm{p}<0,05)$. At 21 days, only the inflammatory infiltrate parameter exhibited small variation between groups, where it was found to be more severe for Curcumin, after 30 seconds and one min of exposure to the light, with significant differences when compared to the control $(\mathrm{p}<0,05)$. At the final period of 63 days, the tissue compatibility was observed to the two photosensitizers, which did not present significant differences for the evaluated parameters, regardless the duration of time of the laser application (Table IV).

Table IV - Statistical analyses of median values obtained on Phase 2 related to collagen fiber formation, tissue thickness and inflammatory infiltrate, after using the photosensitizers Phenothiazine chloride solution and Curcumin in the periods of 7,21 and 63 days (1Q: $1^{\circ}$ quartile; 3Q: $3^{\circ}$ quartile)

\begin{tabular}{|c|c|c|c|c|}
\hline $\begin{array}{l}\text { Experimental } \\
\text { Periods }\end{array}$ & Groups & $\begin{array}{c}\text { Colagen Fiber Formation } \\
\text { (1Q-3Q) }\end{array}$ & $\begin{array}{c}\text { Tissue } \\
\text { Thickness } \\
(10-3 Q)\end{array}$ & $\begin{array}{l}\text { Inflammatory } \\
\text { Infiltrate. (1Q-3Q) }\end{array}$ \\
\hline \multirow{8}{*}{7 days } & Phenothiazine chloride solution $30 \mathrm{~s}$ & $1^{a}(1-1)$ & $1^{b}(1-1)$ & $2^{\mathrm{a}}(2-2)$ \\
\hline & Phenothiazine chloride solution $1 \mathrm{~min}$ & $1^{a}(1-2)$ & $1^{b}(1-1)$ & $\mathrm{ab}(1-2)$ \\
\hline & Phenothiazine chloride solution $2 \mathrm{~min}$ & $1^{a}(1-2)$ & $2^{a}(1-2)$ & $2^{a}(2-2,25)$ \\
\hline & Curcumin $30 \mathrm{~s}$ & $1^{a}(1-2)$ & $1^{b}(1-1)$ & $1^{\mathrm{ab}}(1-1)$ \\
\hline & Curcumin 1 min & $2^{a}(1-2)$ & $1^{b}(1-1)$ & $\mathrm{ab}^{\mathrm{ab}}(1-2)$ \\
\hline & Curcumin 2 min & $1 \mathrm{a}(1-2)$ & $2^{a}(1-2)$ & $2^{\mathrm{ab}}(1-2)$ \\
\hline & Control & $1^{a}(1-1)$ & $1^{b}(1-1)$ & $0^{\mathrm{b}}(0-0)$ \\
\hline & $\begin{array}{c}\text { p value } \\
\text { (Kruskall-Wallis test) }\end{array}$ & $p=0,104$ & $p=0,003$ & $p<0,001$ \\
\hline \multirow{8}{*}{21 days } & Phenothiazine chloride solution $30 \mathrm{~s}$ & $2^{a}(1-2)$ & $1^{a}(1-1)$ & $1^{a}(1-1)$ \\
\hline & Phenothiazine chloride solution $1 \mathrm{~min}$ & $1^{a}(1-2)$ & $1^{a}(1-2)$ & $\mathrm{ab}^{\mathrm{ab}}(0-1)$ \\
\hline & Phenothiazine chloride solution $2 \mathrm{~min}$ & $1^{a}(1-2)$ & $1^{a}(1-1)$ & $\mathrm{ab}^{\mathrm{ab}}(0-1)$ \\
\hline & Curcumin $30 \mathrm{~s}$ & $1^{a}(1-2)$ & $1^{a}(1-2)$ & $0^{\mathrm{ab}}(0-1)$ \\
\hline & Curcumin 1 min & $1^{a}(1-1)$ & $1^{a}(1-2)$ & $1^{a}(1-1)$ \\
\hline & Curcumin 2 min & $2^{\mathrm{a}(1-2)}$ & $1^{a}(1-1)$ & $\mathrm{ab}^{\mathrm{ab}}(0-1)$ \\
\hline & Control & $1^{a}(1-1)$ & $1^{\mathrm{a}}(1-1)$ & $0^{b}(0-0)$ \\
\hline & $\begin{array}{c}\text { p value } \\
\text { (Kruskall-Wallis test) }\end{array}$ & $p=0,139$ & $p=0,256$ & $p=0,008$ \\
\hline \multirow{8}{*}{63 days } & Phenothiazine chloride solution $30 \mathrm{~s}$ & $1^{a}(1-2)$ & $2^{a}(1-2)$ & $0^{\mathrm{a}}(0-0)$ \\
\hline & Phenothiazine chloride solution $1 \mathrm{~min}$ & $1,5^{\mathrm{a}}(1-2)$ & $1^{a}(1-2)$ & $0^{a}(0-0,25)$ \\
\hline & Phenothiazine chloride solution $2 \mathrm{~min}$ & $2^{a}(1-2)$ & $1^{a}(1-2)$ & $0^{\mathrm{a}}(0-0)$ \\
\hline & Curcumin $30 \mathrm{~s}$ & $2^{a}(1-2)$ & $1^{a}(1-1)$ & $0^{a}(0-1)$ \\
\hline & Curcumin $1 \mathrm{~min}$ & $1^{a}(1-2)$ & $1^{a}(1-1)$ & $0^{a}(0-0)$ \\
\hline & Curcumin 2 min & $2^{a}(1,75-2)$ & $1,5^{\mathrm{a}}(1-2)$ & $0,5^{\mathrm{a}}(0-1,25)$ \\
\hline & Control & $\mathrm{p}^{\mathrm{a}(1-1)}$ & $\mathrm{p}^{\mathrm{a}(1-1)}$ & $0^{a}(0-0)$ \\
\hline & $\begin{array}{c}\text { p value } \\
\text { (Kruskall-Wallis test) }\end{array}$ & $p=0,212$ & $p=0,132$ & $p=0,142$ \\
\hline
\end{tabular}

$\mathrm{s}=$ seconds; $\min =\min$.

* Different superscript letters indicate statistically significant differences (Dunn's Post-test; $p<0,05$ ).

$30 \mathrm{~s}, 1 \mathrm{~min}$ and $2 \mathrm{~min}$ are regarding the application time refer to the different exposure times of the photosensitizers to the laser or LED. 

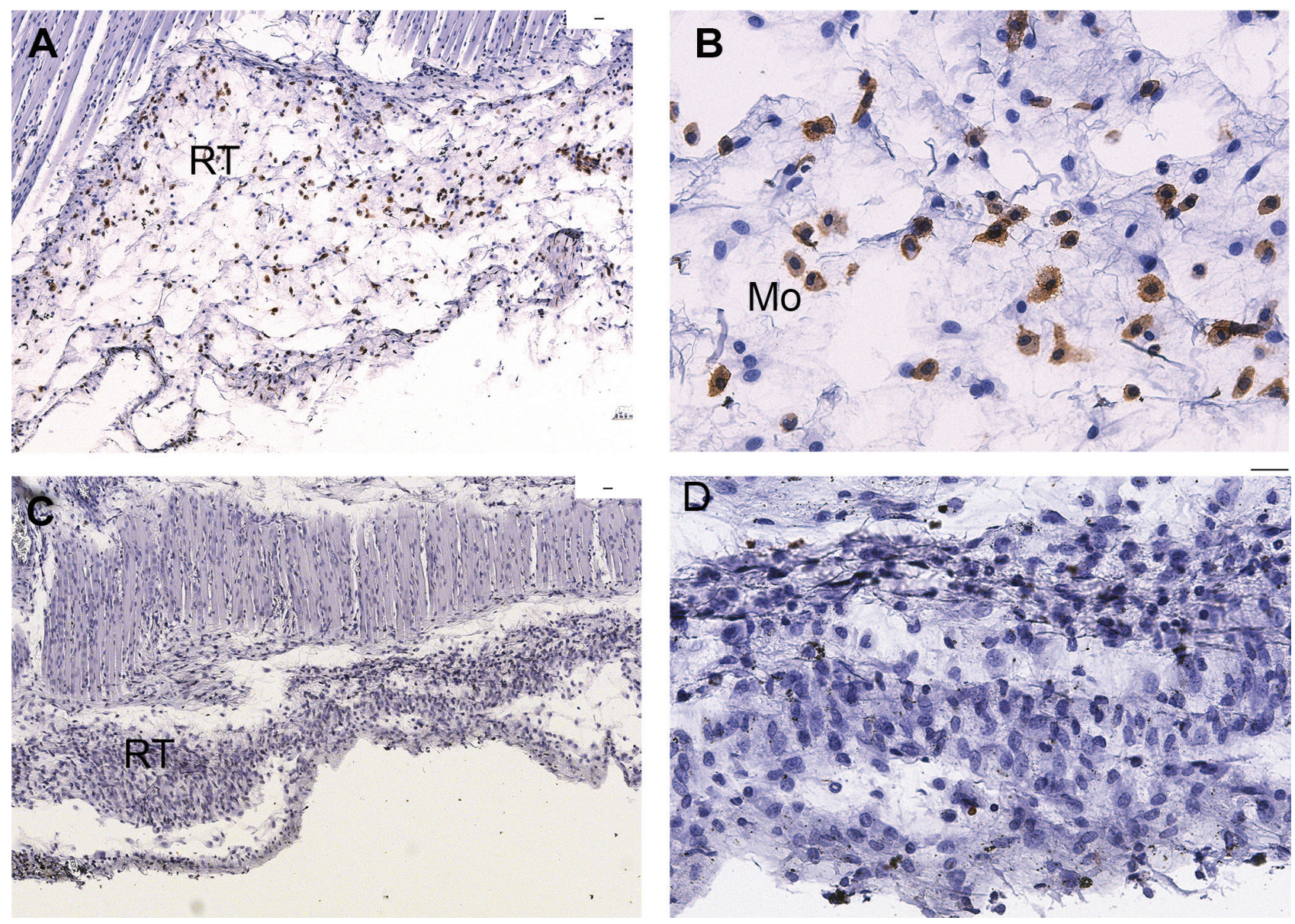

Figure 3 - Microscopic aspects representing immunohistochemical staining for neutrophils (A and B) and macrophages (C and D), in the subcutaneous conjunctive tissue after PDT. Mo: macrophage, TR: reactive tissue (scale bar $=50 \mu \mathrm{m})$.

\section{DISCUSSION}

This study evaluated the inflammatory response of the subcutaneous tissue of isogenic mice after PDT application, using two photosensitizers activated by laser and LED in three experimental periods. The contact of different materials with the connective tissues triggers an inflammatory response from the interaction between the components of the material and the vascular and cellular responses to its aggressive potential [21]. The criteria used to evaluate the tissue response in this study included events related to the body response to the injury caused by the tested materials, such as collagen fiber formation, tissue thickness and inflammatory infiltrate in the affected area [20]. According to Taha et al., (2016) the analysis of the inflammatory process is criteria of great importance to evaluate the biologic compatibility of material, and should include parameters going beyond the number of inflammatory cells [22].

Also, the evaluation of materials in subcutaneous tissues is highly adopted in Endodontics [22,23]. Furthermore, there is a direct correlation between the formation of the reactional fibrotic capsule and the capacity of the tissue to be tolerant to the tested material, once that this reflects an immune reaction to a foreign body recognized by the biologic system [22]. Variations in inflammatory response between the specimens in 7 to 21 days possibly occurred due to the simultaneity of the events triggered by the reaction of the material with the surgical act for its placement, in addition to the characteristics inherent to the inflammatory process in this period. In the final experimental period, at 60 days, tissue compatibility was observed, suggesting the body's resolution for injury caused by the material, and it 
is unlikely that the inflammatory process will recur again unless there is bacterial contamination [24].

Although the events related to the inflammatory process are known to be of fundamental importance to determine the aggressive potential of materials and treatments, when discussing the PDT, there is not enough studies in Dentistry showing the microscopic alterations in different tissues (oral mucosa, periodontal tissues, cutaneous burn and dorsal wounds in mice) after using this type of treatment [6-12].

Specifically, in Endodontics, which is one of the areas of application of PDT in Dentistry, only few studies evaluated tissue reactions to this therapy. Three of these studies $[2,10,12,25]$, performed by our research group, evaluated the histopathologic characteristics of the periapical tissue in dog's teeth, after endodontic treatment using PDT protocols. In the present study, the evaluation of the subcutaneous tissue in mice, aimed to evaluate the tissue compatibility, without the presence of bacteria or pre-existent pathologic processes. In the studies mentioned above, the experimental models used were teeth with experimental induced periapical lesion, besides the bacteria presence, which influenced the characteristics of the inflammatory infiltrate and the repair process. Even so, favorable results after PDT were found by the authors.

Both Silva et al. (2012) [2] and Borsatto et al. (2016) [10] highlighted that the PDT parameters could have influenced their results. Silva et al. (2019) [25] suggested that the used aPDT protocol stimulated the repair process, however the CH-based dressing promoted better apical periodontitis repair. Therefore, new studies must establish a safe protocol, enabling the inactivation of bacteria without causing aggression to the host apical and periapical tissues. For this reason, performing studies evaluating the different parameters used of the PDT are justified.

Two photosensitizers were selected in this study. The photosensitizers have their antiinflammatory activity related to their ability to inhibit the action of mediators involved in the inflammatory process, such as cyclooxygenase, interleukins, leukotrienes, prostaglandins, nitric oxide and tumor necrosis factor alpha (TNF- $\alpha$ ) [26]. This anti-inflammatory potential probably can be attributed to the low intensity tissue reaction obtained in the groups treated in the present study.

The first photosensitizer, the Helbo Blue Photosensitizer, is a Phenothiazine chloride solution. The use of this type of photosensitizers is established in the literature by many studies $[1,18]$. In particular, the Helbo Blue Photosensitizer, used in this study already had its efficiency evaluated, in PDT [2,27]. Also, the concentrations showed antimicrobial activity on previous studies $[18,27]$ and satisfactory tissue response in dog's teeth with periapical lesion [2]. Similarly, in our study, it was showed a mild to moderate fiber collagen formation process and absent/mild inflammatory infiltrate in the later period.

Despite the fact that Curcumin have been used in diverse therapeutic modalities for a long time [28], its action as photosensitizer agent with antimicrobial activity is relatively recent [4,7]. Unlike the Phenothiazine chloride solution, there is not a commercial product, ready to be used. Therefore, in this study, the Curcumin was used in a concentration of $0,0074 \mathrm{mg} / \mathrm{mL}$, reported by Frota et al., (2015) to show antimicrobial activity [4]. In the present study, the Curcumin also presented a favorable tissue response at the final period of 63 days. This can be attributed to the fact that, as described above, the Curcumin is able to regulate an amount of transcription factors, cytokines, kinases, adhesion molecules, and enzymes related to inflammation process [29].

The action of light over tissues is as important in the PDT results as the photosensitizers' effect. The application with the correct parameters, can promote healing of wounds, proliferation of fibroblasts, collagen synthesis and deposition, growth factors and ATP production, proliferation of undifferentiated epidermal cells, as well as the decrease of the number of inflammatory cells [30]. The results of the present study showed that in the final periods ( 21 and 63 days) the three exposure durations to the light (30 seconds, $1 \mathrm{~min}$ or $2 \mathrm{~min}$ ) exhibited tissue compatibility. However, in Dentistry, there are no reports in the literature evaluating the compatibility of tissue after a variation of the exposure duration with laser irradiation in PDT.

Considering the relation between cellular types and the stages of inflammatory process, the 
absence of staining for neutrophils, obtained in the present study, is justified, since this is a short life cell and only present during the initial stages of the process of inflammation. Also, it suggests that the possible initial negative effect caused by PDT was not persistent. For the same reasons, in the present study, the macrophages were positively stained, since they are long-life cells and present in every stage of the inflammation process [20]. According to Wataha et al., (2012), the monocytemacrophage-mediated collagen fibrous capsule acts as a protective barrier between the material and the tissues [31]. Thus, the similarity of the histopathological findings between the treated groups and the controls, in the present study, shows that the application of aPDT was not aggressive to the tissues.

Furthermore, in the present study, the evaluation in subcutaneous tissue had as objective to evaluate the tissue compatibility, without the presence of bacteria or of preexisting pathological processes. The presence of bacteria influences the characteristics of the inflammatory infiltrate and the course of the repair.

Therefore, it is evident that direct comparisons of the present study with the other findings in the literature is difficult, since there is a lack of studies evaluating PDT protocols in subcutaneous tissues. Even if results of studies evaluating other tissues response to this therapy were used to our findings, it is not possible to assure that this response represents exactly the same inflammatory reactions. Such considerations are important, once the characteristics of the target tissue, as well as the photosensitizer and light source parameters have great influence in the effects of PDT [3].

The present study proved that, at the final experimental period (63 days), the two photosensitizers used in the two phases, Phenothiazine chloride solution and Curcumin, presented tissue compatibility. Clinical studies evaluating this protocol are still needed, in order to provide further support for indication and use of PDT by clinicians in Endodontics.

\section{CONCLUSION}

Based on the results obtained with the experimental conditions of this study, it was possible to conclude that the two photosensitizers presented proper tissue compatibility, at the final experimental period, regardless the duration of time of the laser or LED application.

\section{Acknowledgements}

This study was financed in part by the Coordenação de Aperfeiçoamento de Pessoal de Nível Superior - Brasil (CAPES). Authors thanks to São Paulo State Research Foundation (FAPESP) for the financial support (2015/18167-4), to Helbo Photodynamic Systems GmbH \& Co by providing photosensitizer and laser and to Professor Heitor Marques Honório (Pediatrics, Orthodontics and Public Healthy Department of the School of Dentistry of Bauru - University of São Paulo) for the contribution in the statistical analysis.

\section{REFERENCES}

1. Soukos NS, Chen PS, Morris JT, Ruggiero K, Abernethy AD, Som S, et al. Photodynamic therapy for endodontic disinfection. JEndod. 2006 0ct;32(10):979-84. doi: 10.1016/j.joen.2006.04.007

2. Silva LA, Novaes AB Jr, de Oliveira RR, Nelson-Filho P, Santamaria M Jr, Silva RA. Antimicrobial photodynamic therapy for the treatment of teeth with apical periodontitis: a histopathological evaluation. J Endod. 2012 Mar;38(3):360-6. doi: 10.1016/j.joen.2011.12.023

3. Chrepa V, Kotsakis GA, Pagonis TC, Hargreaves KM. The effect of photodynamic therapy in root canal disinfection: a systematic review. $\mathrm{J}$ Endod. 2014 Jul;40(7):891-8. doi: 10.1016/j.joen.2014.03.005

4. da Frota MF, Guerreiro-Tanomaru JM, Tanomaru-Filho M, Bagnato VS, Espir $\mathrm{CG}$, BerbertFL. Photodynamic therapy in root canals contaminated with Enterococcus faecalis using curcumin as photosensitizer. Lasers Med Sci. 2015 Sep;30(7):1867-72. doi: 10.1007/s10103-014-1696-z

5. Bumb SS, Bhaskar DJ, Agali CR, Punia H, Gupta V, Singh V, et al... Assessment of photodynamic therapy (PDT) in disinfection of deeper dentinal tubules in a root canal system: an in vitro study. J Clin Diagn Res. 2014 Nov;8(11):ZC67-71. doi: 10.7860/JCDR/2014/11047.5155

6. Luan XL, Qin YL, Bi LJ, Hu CY, Zhang ZG, Lin J, et al. Histological evaluation of the safety of toluidine blue-mediated photosensitization to periodontal tissues in mice. Lasers Med Sci. 2009 Mar;24(2):162-6. doi: 10.1007/s10103007-0513-3

7. Okada N, Muraoka E, Fujisawa S, Machino M. Effects of curcumin and capsaicin irradiated with visible light on murine oral mucosa. In Vivo. 2012 Sep-0ct;26(5):759-64.

8. Garcia VG, Longo M, Gualberto Júnior EC, Bosco AF, Nagata MJ, Ervolino $\mathrm{E}$, et al. Effect of the concentration of phenothiazine photosensitizers in antimicrobial photodynamic therapy on bone loss and the immune inflammatory response of induced periodontitis in rats. J Periodontal Res. 2014 0ct;49(5):584-94. doi: 10.1111/jre.12138

9. CruzÉde P,Campos L, Pereira Fda S, Magliano GC, Benites BM, AranaChavez VE, et al. A. Clinical, biochemical and histological study of the effect of antimicrobial photodynamic therapy on oral mucositis induced by 5 -fluorouracil in hamsters. Photodiagnosis Photodyn Ther. 2015 Jun;12(2):298-309. doi:10.1016/j.pdpdt.2014.12.007 
10. Borsatto MC, Correa-Afonso AM, Lucisano MP,Bezerra da Silva RA Paula-Silva FW, Nelson-Filho P, et al. One-session root canal treatment with antimicrobial photodynamic therapy (aPDT): an in vivo study. Int Endod J. 2016 Jun;49(6):511-8. doi: 10.1111/iej.12486

11. Deyhimi P, Khademi H, Birang R, Akhoondzadeh M. Histological evaluation of wound healing process after photodynamic therapy of rat oral mucosal ulcer. J Dent (Shiraz). 2016 Mar;17(1):43-8.

12. Hidalgo $L R$, da Silva $L A$, Nelson-Filho $P$, da Silva RA, de Carvalho FK, Lucisano MP, et al. Comparison between one-session root canal treatment with aPDT and two-session treatment with calcium hydroxide-based antibacterial dressing, in dog's teeth with apical periodontitis. Lasers Med Sci. 2016 Sep;31(7):1481-91. doi: 10.1007/s10103-016-2014-8

13. Pillusky FM, Barcelos RCS, Vey LT,Barin LM, de Mello Palma V, Maciel $\mathrm{RM}$, et al. Antimicrobial photodynamic therapy with photosensitizer in ethanol improves oxidative status and gingival collagen in a short-term in periodontitis. Photodiagnosis Photodyn Ther. 2017 Sep;19:119-127. doi: 10.1016/j.pdpdt.2017.05.010

14. Filipini SMR, Campagnolo CB, Dutra DAM, Maciel RM, Danesi CC, Kantorski KZ. Adjunctive antimicrobial photodynamic therapy using methylene blue/ ethanol formulation in experimental periodontitis in diabetic rats: short-term results. Lasers Med Sci. 2019 Aug;34(6):1253-60. doi:10.1007/s10103-01902733-4

15. Ervolino E, Statkievicz C, Toro LF, de Mello-Neto JM, Cavazana TP,Issa JPM, et al. Antimicrobial photodynamic therapy improves the alveolar repair process and prevents the occurrence of osteonecrosis of the jaws after tooth extraction in senile rats treated with zoledronate. Bone. 2019 Mar;120:101-13. doi: 10.1016/j.bone.2018.10.014

16. Luan XL, Qin YL, Bi LJ, Hu CY, Zhang ZG, Lin J, et al. Histological evaluation of the safety of toluidine blue-mediated photosensitization to periodontal tissues in mice. Lasers Med Sci. 2009 Mar;24(2):162-6. doi: 10.1007/s10103007-0513-3

17. Garcia VG, Longo M, Gualberto Júnior EC, Bosco AF, Nagata MJ, Ervolino $E$, et al. Effect of the concentration of phenothiazine photosensitizers in antimicrobial photodynamic therapy on bone loss and the immune inflammatory response of induced periodontitis in rats. J Periodontal Res. 2014 0ct;:49(5):584-94. doi: 10.1111//jre.12138

18. $\mathrm{Ng} \mathrm{R}$, Singh F, Papamanou DA, Song X, Patel C, Holewa C, et al. Endodontic photodynamic therapy ex vivo. JEndod. 2011Feb;37(2):217-22. doi: 10.1016/j. joen.2010.10.008

19. Wikene KO, Hegge AB, Bruzell E, Tønnesen HH. Formulation and characterization of lyophilized curcumin solid dispersions for antimicrobial photodynamic therapy (aPDT): studies on curcumin and curcuminoids LII. Drug Dev Ind Pharm. 2015 Jun;41(6):969-77. doi: 10.3109/03639045.2014.919315
20. Queiroz AM, Assed S, Consolaro A, Nelson-Filho P, Leonardo MR, Silva $\mathrm{RA}$, et al. Subcutaneous connective tissue response to primary root canal filling materials. Braz Dent J. 2011;22(3):203-11. doi: 10.1590/s010364402011000300005

21. Anderson JM, Rodriguez A, Chang DT. Foreign body reaction to biomaterials. Semin Immunol. 2008 Apr;20(2):86-100. doi: 10.1016/j.smim.2007.11.004

22. Taha NA, Safadi RA, Alwedaie MS. Biocompatibility evaluation of endosequence root repair paste in the connective tissue of rats. J Endod. 2016 0ct;42(10):1523-8. doi:10.1016/j.joen.2016.07.017

23. Takamiya AS, Monteiro DR, Bernabé DG, Gorup LF, Camargo ER, Gomes-Filho $\mathrm{JE}$, et al. In vitro and in vivo toxicity evaluation of colloidal silver nanoparticles used in endodontic treatments. J Endod. 2016 Jun;42(6):953-60. doi: 10.1016/j.joen.2016.03.014

24. Kao CT, Tsai CH, Huang TH. Tissue and cell reactions to implanted root-end filling materials. J Mater Sci Mater Med. 2006 Sep;17(9):841-7. doi: 10.1007/ s10856-006-9844-z

25. Silva LABD, Lopes ZMS, Sá RC, Novaes Júnior AB, Romualdo PC, Lucisano $\mathrm{MP}$, et al. Comparison of apical periodontitis repair in endodontic treatment with calcium hydroxide - dressing ans a PDT. Braz Oral Res. 2019;33:e092

26. Silva LS, Catalão CH, Felippotti TT, Oliveira-Pelegrin GR, Petenusci S, de Freitas $L A$, et al. Curcumin suppresses inflammatory cytokines and heat shock protein 70 release and improves metabolic parameters during experimental sepsis. Pharm Biol. 2017 Dec;55(1):269-76. doi: 10.1080/13880209.2016.1260598

27. de Oliveira RR, Novaes AB Jr, Garlet GP, de Souza RF, Taba M Jr, Sato S, etal. The effect of a single episode of antimicrobial photodynamic therapy in the treatment of experimental periodontitis. Microbiological profile and cytokine pattern in the dog mandible. Lasers Med Sci. 2011 May;26(3):359-67. doi: 10.1007/s10103-010-0864-z

28. Hatcher H, Planalp R, Cho J, Torti FM, Torti SV. Curcumin: from ancient medicine to current clinical trials. Cell Mol Life Sci. 2008 Jun;65(11):1631-52. doi:10.1007/s00018-008-7452-4

29. Maulina T, Diana H, Cahyanto A, Amaliya A. The efficacy of curcumin in managing acute inflammation pain on the post-surgical removal of impacted third molars patients: a randomised controlled trial. J Oral Rehabil. 2018 Sep;45(9):677-83. doi: 10.1111/joor.12679

30. Percival SL, Francolini I, Donelli G. Low-level laser therapy as an antimicrobial and antibiofilm technology and its relevance to wound healing. Future Microbiol. 2015;10(2):255-72. doi: 10.2217/fmb.14.109

31. Wataha JC. Predicting clinical biological responses to dental materials. Dent Mater. 2012 Jan;28(1):23-40. doi:10.1016/.jdental.2011.08.595

\section{Carolina Maschietto Pucinelli} (Corresponding address)

Department of Pediatric Dentistry, School of Dentistry of Ribeirão Preto, University of São Paulo, Ribeirão Preto, SP, Brazil.

Email: carolinamaschietto@yahoo.com.br

Date submitted: 2020 Jun 30

Accept submission: 2020 Sep 29 